\title{
Pesantren Salaf dan Respons Perubahan: Potret Pengembangan Pondok Pesantren Annur Azzubaidi, Konawe
}

\author{
$\operatorname{Sabdah}^{1} \&$ Sastramayani $^{2}$ \\ ${ }^{1}$ Fakultas Keguruan dan Ilmu Pendidikan, Universitas Lakidende \\ Email: sabdah.unilaki@gmail.com \\ ${ }^{2}$ Fakultas Keguruan dan Ilmu Pendidikan, Universitas Lakidende \\ Email: sastramayani.unilaki@gmail.com
}

\begin{abstract}
Abstrak
Meskipun pesantren telah membuktikan diri sebagai salah satu pemasok sumber daya manusia di Indonesia, namun saat ini tantangannya semakin kompleks. Persaingan antar lembaga pendidikan Islam, atau bahkan dengan pendidikan berlabel umum mestinya menjadi salah satu perhatian para pengelola pondok, sehingga terjaga relevansinya dengan perkembangan. Melalui pendekatan kualitatif, artikel ini menyajikan hasil penelusuran di Pesantren Annur Azzubaidi, sebuah pesantren tradisional (salaf) di Konawe. Pandangan bahwa lembaga pendidikan saat ini harus menyiapkan diri dalam iklim kompetitif, ternyata bagi pesantren ini tidak demikian. Pimpinan menganggap bahwa niat kompetisi dapat mengalihkan semangat awal pendirian pesantren sebagai sarana pengabdian kepada sang pencipta. Kompetisi adalah godaan-godaan duniawi yang dapat mengganggu niat suci dalam mendidik generasi yang berakhlak mulia. Respon lembaga ini dengan mengakomodir sistem pendidikan modern dalam bentuk madrasah hanyalah bentuk memahami kebutuhan peserta didik. Konservatisme dalam arti mempertahankan tradisi pesantren masih sangat kuat di Pesantren Annur Azzubaidi.
\end{abstract}

\section{Kata Kunci: Kompetisi, Perubahan, Pesantren Salaf}


Salaf Boarding School and Response to Change: Portrait of Annur Azzubaidi Boarding School Development, Konawe

\title{
$\operatorname{Sabdah}^{1} \&$ Sastramayani $^{2}$
}

${ }^{1}$ Fakultas Keguruan dan Ilmu Pendidikan, Universitas Lakidende

Email: sabdah.unilaki@gmail.com

${ }^{2}$ Fakultas Keguruan dan Ilmu Pendidikan, Universitas Lakidende

Email: sastramayani.unilaki@gmail.com

\begin{abstract}
Although pesantren have proven themselves to be one of the suppliers of human resources in Indonesia, the challenges are now more complex. Competition between Islamic educational institutions, or even with public labeled education should be one of the concerns of the managers of the cottage, so that its relevance to development is maintained. Through a qualitative approach, this article presents search results at the Annur Azzubaidi Pesantren, a traditional pesantren (salaf) in Konawe. The view that educational institutions must now prepare themselves in a competitive climate, apparently for pesantren this is not the case. The leadership considers that the intention of competition can divert the initial spirit of the establishment of pesantren as a means of devotion to the creator. Competition is worldly temptations that can disrupt the sacred intentions in educating noble-minded generations. The response of this institution by accommodating the modern education system in the form of madrasas is only a form of understanding the needs of students. Conservatism in the sense of maintaining the pesantren tradition is still very strong in the Annur Azzubaidi Islamic Boarding School.
\end{abstract}

Keywords: Competition, Change, Salaf Boarding School 


\section{Pendahuluan}

Secara historis, kehadiran pesantren di nusantara telah menjembatani kebutuhan masyarakat terhadap pendidikan, terutama bagi kelas menengah-bawah, yang saat itu tidak mendapatkan akses untuk belajar. Berbeda dengan kalangan bangsawan, pedagang, dan penjajah yang memiliki sekolah khusus ${ }^{1}$. Hal ini menyebabkan pesantren menjadi akrab dengan masyarakat pinggiran (rakyat) ${ }^{2}$, atau bahkan dikenal sebagai fenomena desa ${ }^{3}$. Sehingga kegiatan-kegiatan pesantren lebih banyak bersentuhan dengan persoalan pedesaan, misalnya pembinaan remaja desa $^{4}$, dan pembangunan masyarakat masyarakat pedesaan ${ }^{5}$.

Seiring perkembangan zaman, pesantren-pesantren di Indonesia berupaya adaptif terhadap perubahan lingkungan. Mereka makin menyadari bahwa menyesuaikan diri terhadap perubahan lingkungan merupakan upaya menjaga relevansi pesantren dengan kebutuhan masyarakat, yang berarti juga memelihara mutu pesantren ${ }^{6}$. Berbagai model pesantren bermunculan, tidak lagi dalam bentuk salaf dan khalaf saja, tetapi lebih spesifik lagi, misalnya pesantren pertanian $^{7}$, dan pesantren wirausaha ${ }^{8}$.

1 Syahrul, S. (2020). Strategi Pengembangan Lembaga Pendidikan: Menggali Spirit PM Gontor 7 Putera, Sulawesi Tenggara. Shautut Tarbiyah, 24(2), 334-360.

${ }^{2}$ Ch, M. (2012). PESANTREN RAKYAT: Perhelatan Tradisi Kolaboratif Kaum Abangan dengan Kaum Santri Pinggiran Desa Sumberpucung Kabupaten Malang. El Harakah (terakreditasi), 14(1), 115-134.

${ }^{3}$ Badarwan, B. (2018). Perilaku Sukarela di Pesantren: Karakter Langka di tengah Pusaran Pragmatisme SDM Lembaga Pendidikan. Shautut Tarbiyah, 24(1), 19-36.

${ }^{4}$ Wibowo, A. (2016). Peran Pondok Pesantren Al-Haidar Dan Pembinaan Remaja Desa Penjalin Brangsong Kendal (Doctoral dissertation, UIN Walisongo).

${ }^{5}$ Mustari, M., \& Rahman, M. T. (2012). Ekonomi Pesantren: Manajemen Pesantren dalam Pembangunan Masyarakat Desa (Vol. 1, No. 1). Lintang Publishing.

${ }^{6}$ Syahrul, S. (2017). Tanggung Jawab Sosial Pesantren: Studi pada Pondok Pesantren Al Munawwarah Pondidaha, Konawe. Shautut Tarbiyah, 23(2), 120-134.

7 Widodo, M. S. (1995). Pesantren Darul Fallah: eksperimen pesantren pertanian. Pesantren dan Pembaharuan, 122-23. Lihat pula Ramdhani, M. R. (2017). IMPLEMENTASI PENDIDIKAN LIFE SKILL DI PESANTREN PERTANIAN DARUL FALLAH BOGOR. TADBIR MUWAHHID, 4(2).

${ }^{8}$ Ghofur, A., Asiyah, N., \& Shofiyullah, M. (2017). Pesantren Berbasis Wirausaha (Pemberdayaan Potensi Enterpreneurship Santri di Beberapa Pesantren 
Respons terhadap perubahan tidak lagi menjadi gerakan pesantren khalaf, tetapi juga pada pesantren salaf. Karenanya, perbedaan antara salaf dan khalaf dalam tradisi pesantren semakin tipis. Kebutuhan untuk bertahan dalam persaingan pendidikan mengharuskan pesantren untuk menyesuaikan diri terhadap perubahan zaman. Inovasi-inovasi dilakukan oleh pesantren ${ }^{9}$, misalnya mengakomodir sistem madrasah ${ }^{10}$, sekolah umum ${ }^{11}$, dan mendirikan peruguruan tinggi ${ }^{12}$.

Pondok Pesantren Annur Azzubaidi merupakan salah satu pesantren bertradisi salaf di Konawe. Kehadiran pesantren ini telah menyumbang berbagai kemajuan dalam kehidupan keagamaan masyarakat luas. Menariknya, upaya adaptif pesantren ini terhadap perubahan bukanlah dalam kerangka kompetisi, tetapi menjaga tanggungjawab mendidik masyarakat.

\section{Metode}

Penelusuran lapangan dalam kajian ini menggunakan prosedur penelitian kualitatif, di mana peneliti menjadi instrumen utama, berinteraksi secara aktif dengan pelaku peristiwa, menyelami berbagai kondisi pesantren Annur Azzubaidi, dan merasakan kegiatan-kegiatan di pesantren tersebut ${ }^{13}$. Karenanya, proses wawancara, mengamati secara partisipatif, dan membaca dokumen-dokumen menjadi teknik

Kaliwungu Kendal). Dimas: Jurnal Pemikiran Agama untuk Pemberdayaan, 15(2), 19-52.

9 Syahrul, S. (2015). Kepemimpinan dan Inovasi Lembaga Pendidikan (Pengalaman Pondok Gontor VII Putra Sulawesi Tenggara). Al-Ta'dib, 8(1), 82-100.

${ }^{10}$ Usman, M. I. (2013). Pesantren Sebagai Lembaga Pendidikan Islam (Sejarah Lahir, Sistem Pendidikan, Dan Perkembangannya Masa Kini). Jurnal alHikmah, 14(1), 127-146.

${ }^{11}$ Supriatna, E., Bahruddin, E., Hafidhuddin, D., \& Saefuddin, D. (2014). Konsep dan Implementasi Pendidikan Karakter di Sekolah Menengah Kejuruan (SMK) Berbasis Pondok Pesantren. Ta'dibuna: Jurnal Pendidikan Islam, 3(2), 100114.

12 Ikhsanuddin, M., Millah, A. S., \& Machalli, I. (2013). Pengembangan Kurikulum Perguruan Tinggi Pesantren: Studi Pada Ma'had Al-'Aly Pondok Pesantren Situbondo, al-Munawwir Krapyak dan Wahid Hasyim Sleman. Jurnal AlNur, 5(2), 261-289.

${ }^{13}$ Dalam penelitian kualitatif, objek penelitian merupakan gabungan dari interaksi para aktor, tempat dan kegiatan. Lihat Sugiyono, P. (2005). Memahami penelitian kualitatif. Bandung: Alfabeta. 
utama dalam pengumpulan data ${ }^{14}$. Analisis data menggunakan prosedur dari Miles dan Huberman, yaitu melakukan pemilahan data, menyajikan data, dan menarik kesimpulan ${ }^{15}$.

\section{Hasil dan Pembahasan}

\section{Kelahiran dan Perkembangan PPAnnur Azzubaidi}

Pondok Pesantren Annur Azzubaidi berlokasi Jl. S. Palulu No.

30 Desa Larowiu Kec. Meluhu Kab. Konawe Prov. Sulawesi Tenggara. Pendirinya adalah Ustadz Anang Zubaidi pada tahun 1990. Pimpinan saat ini adalah Ustadz Muhammad Imron, S. Pd, M.Pd. Jumlah santri 217 orang, sedangkan jumlah Ustadz/guru 32 Orang. Menyelenggarakan pendidikan formal mulai dari jenjang RA (raudhatul athfal), MI (madrasah ibtidaiyah), MTs (madrasah tsanawiyah), hingga MA (madrasah aliyah). Kegiatan non formal dalam bentuk Non Formal : MDA, MDW, dan majelis taklim. Adapun ciri khas pondok ini adalah tahfidz (hapalan Al-Qur'an), Fiqh Tauhid, dan pengembangan bakat/prestasi.

Berawal dari sebuah kelompok pengajian Ustadz Anang Zubaidi memulai perjuanganya. Kehadiran beliau di lokasi transmigrasi tepatnya di desa Larowiu Kec. Meluhu Kab. Konawe Prov. Sul-Tra ternyata sangat dirindukan oleh masyarakat dalam rangka pembinaan dan pengembangan agama Islam. Sekitar tahun 1989 rintisan itu dimulai. Sambutan dan antusias masyarakat begitu tinggi, walaupun semula kehadiran ust. Anang Zubaidi hanya kunjungan keluarga. Namun akhirnya beliau bersedia untuk tinggal menetap meneruskan rintisan perjuanganya.

Di akhir tahun 1989 beliau memohon restu kepada gurunya K.H Burhanuddin Hamid Pengasuh P.P ANNUR I Bululawang Malang, juga kepada kedua orang tuanya yang tercinta, untuk meneruskan rintisan perjuanganya di Sulawesi Tenggara. Kedua orang tuanya menyarankan agar membeli sebidang tanah. Alhamdulillah hajat terpenuhi. Semula Ust.Anang merintis kelompok pengajian di rumah pamanya di Jl. Kelud No. 17. Kini beliau tinggal di Jl. S. Palulu No. 30 yang tidak jauh dari tempat semula. Diatas areal tanah

\footnotetext{
${ }^{14}$ Moleong, L. J. (2006). Metode penelitian kualitatif edisi revisi. Bandung: Remaja Rosdakarya.

${ }^{15}$ Miles, M. B., \& Huberman, A. M. (1992). Analisis Data Kualitatif, penerjamah Tjerjeprohidi.
} 
1/4 Ha itulah akhirnya berdiri sebuah bangunan sederhana yang terdiri dari 4 kamar dengan kontruksi semi permanen.Beliau memberi nama kelompok pengajian "ANNUR" untuk mengabadikan almamaternya.

Pengajian-pengajian di wilayah sekitar kecamatan Meluhu sering dihadiri oleh ust. Anang Zubaidi. Disampaing menyampaikan da'wahnya juga beliau memperkenalkan kelompok pengajian yang diasuhnya, sehingga banyak orang tua yang berkeinginan untuk menitipkan anaknya pada beliau. Mulailah santri berdatangan untuk menimba ilmu. Ketika orang tua santri ditanya dimana anaknya domondokkan? Jawabanya: Di pondokknya pak Zubaidi. Sehingga nama Zubaidi lebih dikenal ketimbang ANNURnya.

Untuk memudahkan kesimpang-siuran penyebutan nama antara Annur dan Zubaidi tanggal 28 Oktober 1990 akhirnya diresmikan sebuah lembaga PP Annur Azzubaidi yang dihadiri oleh tokoh-tokoh agama dan tokoh-tokoh masyarakat.Juga dari pejabat Kanwil Departemen Agama serta para jamaah disekitarnya. Itupun setelah beliau memohon restu dari pengasuh PP ANNUR I Bululawang Malang.Dengan harapan ANNUR AZZUBAIDI kelak sebagai wadah pembinaan akidah,akhlak dan keilmuan mampu menjadi intisari cahaya da' wah agama islam.

Setelah resmi berdiri P.P ANNUR AZZUBAIDI santri mulai berdatangan dari luar daerah. Tahun 1992 santri sudah mencapai sekitar seratus orang. Melihat perkembangan begitu cepat masyarakat membelikan tanah seperempat Ha, disamping Pondok dan diwaqafkan untuk lokasi bangunan masjid Jami'. Selang beberapa tahun setiap ada kunjungan baik pejabat daerah maupun para dermawan mampu membebaskan tanah sekitar lima Ha di kanan kiri lokasi pesantren, sebagai pengembangan pesantren dimasa yang akan datang.

\section{Kondisi Masyarakat sekitar}

PP Annur Azzubaidi berdiri di tengah-tengah lokasi pemukiman transmigrasi yang asal-usulnya dari berbagai macam suku dan daerah yang berbeda. Masyarakatnya sangat kompleks. Adat istiadatnya banyak yang berbeda. Namun semangat perjuangan terhadap agama sangat tinggi. Sehingga dengan berdirinya Pesantren tersebut mampu menjadi motor/penggerak ummat dalam mengamalkan ajaran agama, sekaligus sebagai wadah pemersatu kegiatan keagamaan hingga kini.Bahkan harapan pengasuh untuk menciptakan masyarakat dengan suasana santri mulai nampak. 
Musholla -musholla yang berdiri disetiap lorong sebelum pesantren itu ada, kini telah termanfaatkan dengan baik. Bahkan menjadi tempat-tempat halakah agama ummat disetiap lorong tersebut,yang dibina secara sentral dari Pesantren.Masjid Jami' yang berada ditengah-tengah pondok Pesantren kini sebagai tempat bertemunya masyarakat dikala Shalat Jum'at dan Shalat Id, begitu pula dalam pengajian wetonan Ahad Legi.

\section{Jenjang Pendidikan yang Diselenggarakan}

Bentuk pendidikan di pondok pesantren Annur Azzubaidi semula adalah system salafiyah ya'ni system bandongan, sorogan dan wetonan. Seiring dengan perkembangan zaman serta tuntutan mutu pendidikan maka pada tahun 1994 dirintislah Madrasah Aliyah Annur Azzubaidi. Untuk santri setingkat SD dan SMP menempuh pendidikan di Madrasah Ibtidaiyah dan Tsanawiyah Darul Ulum yang jarak tempuhnya kurang lebih $900 \mathrm{~m}$. dari lokasi pesantren. (berdiri tahun 1983). Pada tahun 1997 MA Annur Azzubaidi resmi terdaftar di Departemen Agama setempat sehingga pada tahun itu pula dipercayakan untuk menyelenggarakan Ujian Negara di sekolah sendiri (sebelumnya siswa menggabung pada MAS Al-Ikhlas Meluhu). Pada tahun 1997 pula didirikan Raudlatul Athfal Annur yang juga beralokasi di dalam Pondok Pesantren.

Pada tahun 1999 masyarakat sepakat agar MI dan MTs Darul Ulum yang jarak tempuhnya agak jauh, untuk dipindah di lokasi pondok pesantren Annur Azzubaidi dengan pertimbangan $80 \%$ siswa dan gurunya berdomisili di PP Annur Azzubaidi. Yang kedua adalah pertimbangan keamanan dan ketertiban santri. Untuk kelangsungan dua lembaga tersebut (MI dan MTs) di serahkan sepenuhnya kepada kyai / pengasuh.

Pada tahun 1999 lengkaplah jenjang pendidikan formal yang ada di PP. Annur Azzubaidi dari RA,MI,MTs hingga Madrasah Aliyah.

Bagi santri yang tidak menempuh pendidikan formal disebabkan lewat usia, sudah tamat (MA) atau factor finansial lain, maka dibina dan dikelompokkan serta diberikan kegiatan sesuai bakat dan kemampuannya.

Untuk pendidikan Al-ur`an dibagi dalam tiga tingkatan yaitu ; a. Tingkat Dasar, b. Tingkat Bin Nadhor, c. Tingkat huffadz (hafalan). Setiap santri baru akan diseleksi dan di tes untuk dimasukkan ke 
kelompok yang sesuai dengan kemampuannya tanpa memandang usia. Sistem pendidikan Al Qur`an memakai sistem sorogan dan setiap santri memiliki buku setoran (daftar hadir) yang ditanda tangani oleh seorang ustadz/ustadzah setelah santri tersebut mengaji / setoran. setiap ahad pagi (ba`da subuh) para santri dibimbing tahsinul qiro`ah. Dan alhamdulillah sejak tahun 1994 telah banyak santri PP. Annur Azzubaidi yang mengantongi prestasi dari tingkat Kecamatan hingga di tingkat Nasional, terutama dibidang hifdzil qur`an, kaligrafi dan cerdas cermat isi kandungan $\mathrm{Al}$-qur`an.

Pengkajian kitab dilaksanakan dengan sistem klasikal (madrasiy). Mengingat masih keterbatasan tenaga pengajar maka pengkajian kitab ini di bagi menjadi empat kelas, dan dengan menggunakan awal tahun ajaran pada bulan Syawal dan semester pada bulan Maulid. Mengingat para santri terdiri dari berbagai suku dan etnis (Bugis, Tolaki, Buton, Muna, Jawa dsb.) maka sistem pengajarannya dikombinasikan yaitu tetap menggunakan metode Klasik (mema`na kalimat perkalimat) kemudian diterjemahkan dan diterangkan dengan bahasa Indonesia.

Kegiatan ekstrakurikuler yang dilaksanakan di pondok pesantren ini antara lain : Khitobah, Marching Band (putra), Nasyid (qosidah Sholawat Annaz Group), ketrampilan menjahit (putri), seni kaligrafi, seni lukis, letter dan suvenir, peternakan dsb. Sebagaimana slogan PP. Annur Azzubaidi “ Wadah kreaktifitas santri"Sebab santri tidak cukup berbekal agama saja, tetapi santri harus dicetak menjadi santri yang trampil dan kreatif memiliki etos kerja, seperti tujuan didirikannya Pondok pesantren ini adalah untuk mencetak kader-kader bangsa yang bertaqwa, ber-Akhlaqul karimah, berwawasan Iptek dan memiliki kreaktifitas dan ketrampilan yang memadai. Jadi kelak siap menjadi masyarakat yang berguna dan siap pakai.

\section{Pendidikan Al-Qur'an Sebagai Ciri Khas :}

Ciri khas pondok ini adalah pendidikan Al-qur`an. walaupun tidak menutup kemungkinan akhir-akhir ini pengkajian kitab (Ilmu Fiqih dan Nahwu atau Shorof) semakin diminati para santri. Tapi ciri khas pondok qur`an tetap tidak tergeser. Sebab satu-satunya pondok di Sulawesi tenggara yang sudah meluluskan santri hafalan bil-ghoib ( hafidz/hafidzah) 30 juz baru dipondok ini. Termasuk diantaranya adalah sebagai sarana pengembangan kreatifitas santri. 


\section{Kesiapan Menghadapi Lingkungan Yang Berubah}

Jumlah santri yang ada di PP. Annur Azzubaidi adalah 320 orang dengan perincian 170 santri Putri dan 150 santri putra. $85 \%$ santri Mukim di Pondok dan yang $15 \%$ santri kalong. Mereka tersebar di lembaga pendidikan yang dikelola PP. Annur Azzubaidi baik jalur Formal maupun non formal.

Para santri diasuh oleh seorang kyai dan dua orang badal serta 31 ustadz atau guru. Yang erdiri dari 10 orang perempuan, dan 21 orang guru laki-laki, dengan kualifikasi 11 orang lulusan S1, 6 orang tamatan D2 dan 14 tamatan MA/SMU. Dibantu dengan 4 orang tenaga administrasi.

Keadaan bangunan di PP.Annur Azzubaidi masih sangat sederhana. Bangunan- bangunan yang sifatnya darurat (dinding papan) masih banyak berdiri di areal pondok ini. tetapi walau sederhana nampak keserasian dan keindahan sebagaimana motto para santri :" Asri serasi penuh preasi”. PP. Annur Azzubaidi memiliki sarana dan prasarana (non formal); 6 ruang mengaji, 1 unit kantor pondok, 8 Lokal Asrama Putra/ putri , 1 unit bangunan Masjid, 1 unit Musholla putri, 6 unit rumah pengasuh dan Ustadz (yang berkeluarga), 2 ruang koperasi, 12 ruang kamar mandi dan WC serta 1 unit sanggar kreatifitas santri.

Untuk pendidikan Formal : 2 ruang gedung RA, 12 ruang belajar MI, MTs dan MA, 3 ruang kantor dan ruang guru, 1 ruang perpustakaan dan 2 ruang WC atau kamar mandi.

PP Annur Azzubaidi adalah salah satu pondok yang sangat independen atau mandiri yang ada di Sul-tra. Sumber dana pokok adalah dari pembayaran Syahriyah, usaha ekonomi produktif (koperasi, ternak kambing, tanaman hias), penerbitan kalender,Album Qasidah sholawat Annaz, wartel, kantin, hasil pertanian (sawah) dan usaha-usaha lain.

Walaupun tidak menutup kemungkinan bantuan sumbangan baik dari perorangan ataupun swasta yang sifatnya tidak mengikat.(berbeda dengan pesantren lain yang sumber pokok pendanaanya sangat ditopang dari Pemda setempat).

Tidak kurang dari 90 piala dan tanda penghargaan berjejar di Almari kantor pondok, ini menunjukkan telah banyak prestasi yang dicapai oleh santri PP. Annur Azzubaidi dalam bidang olah raga, Seni, Keilmuwan MTQ, Festifal Anak Sholeh, Festifal bedug dsb. Sejak ditingkat kecamatan hingga dikancah Nasional. 
Untuk tingkat kabupaten sejak tahun 1994 sampai dengan 2005 dalam kejuaraan MTQ kec. Meluhu (pesertanya $90 \%$ para santri PP. Annur Azzubaidi) selalu memboyong Juara Umum. Dan sejak tahun 1994 pondok ini selalu menyertakan santrinya di tingkat Nasional dalam lomba MTQ dan STQ dibidang Hifdzil Qur`an, cerdas cermat dan kaligrafi.

Berbagai upaya dalam pengembangan ke depan Pondok Pesantren Annur Azzubaidi senantiasa giat mencari kiat-kiat guna lebih luasnya pengalaman yang pada akhirnya mampu memberikan keyakinan kepada ummat islam serta pada dunia pentingnya pendidikan dilingkungan Pondok Pesantren.

Sesuai dengan kemajuan zaman, maka keberadaan pondok pesantren Annur Azzubaidi hadir ditengah tengah -tengah masyarakat sulawesi tenggara tentunya mempunyai peranan yang sangat penting dalam kemajuan generasi muda. Mengingat pondok pesantren adalah lembaga pendidikan tertua di Indonesia yang telah banyak menelorkan para tokoh pahlawan, cendekiawan, ilmuwan dan Ulama`.

Harapan kedepan pondok pesantren ini dapat menjadi lembaga pendidikan dan da wah yang diminati masyarakat khususnya di Sulawesi Tenggara yang siap mencetak generasi bangsa dengan dibekali Imtaq dan Iptek dengan beberapa ketrampilan yang ada.

Akhirnya dengan program-program yang ada kiranya keberadaan Pondok pesantren Annur Azzubaidi dapat diminati dan dinikmati masyarakat dalam memberikan sumbangsihnya kepada agama nusa dan bangsa.

Berdasarkan hasil pengamatan saya pondok pesantren annur azzubaidi semakin tahun pertumbuhan dan perkembangannya semakin Nampak dan terlihat, entah itu dari pembangunannya, santri-santri yang semakin kreatif. Keberhasilan ini merupakan keikhlasan pendiri pondok yang berjuang dengan dengan susah payah ketika merintis pondok tersebut.

Kehadiran pondok di tengah-tengah kampung trans membawa perubahan besar, meskipin butuh waktu lama untuk menjadikan kampung tersebut menjadi kampung yang bernuansa islami. Dan kini kampung tersebut seakan-akan menjadi kampung santri yang mana banyak di kampung tersebut pondok pesanteren dan TPA (Tempat Pengajian Anak) yang mana para pengasuhnya merupakan alumni dari lulusan pondok pesantren annur azzubaidi. 
Tidak tebayang jika di kampung terans tersebut tidak ada pondok pesantren, mungkin keadaan kampung tersebut tidaka akan seperti sekang ini yang mana kalu kita lihat setiap sore anak_anak berbondong-untuk mengaji atau mondok kalong. Yang di maksud mondok kalong yaiu santri yang tidak mondok tetap atau santri yang rumahnya dekat dari pondok, berangkat mondok sore pulang pagi. Kemanjuan bukan hany dalam bidang keagamaan tetapi dalam bidang pendidikan pun di kapung SPF yang mana kampung SPF ini nama kamoung tempat berdirinya pondok pesantren annur azzubaidi. Kampung SPF pendidikan itu luar biasa setiap desa memiliki TK/RA kalu untuk tingkat SD/Mi di SPF ada 4 kemudian untuk tingkat SMP/MTS ada 2 dan untuk tingkat SMA/SMKma ada 3 sekolah. Jadi mas yarakat sekitar SPF di hidangkan dengan pilihan dimana anaknya mau dialanjutkan untuk menempuh pendidikannya.

Pondok pesantren hadir ditengah-tengah masyarak SPF memberikan contoh teladan bagi umat manusia, karena kampung tersebut kampung trans jadi terdiri bergai suku yang beragam budaya namun lebih didominasi suku jawa. Namun kesukuan tida menjadi penghalang untuk masyakar saling berkomukasi justru dengan perbedaan suku dan budaya masyarakt saling menghargai dan menghormati budaya masing-masing mereka jadikan sebgai pengtahuaan.

Berkat adanya pondok pesantren annur azzubaidi melahirkankan majelis-majelis yang ada di kampung sehingga setiap desa meliki mushola-mushola setiap lorong dan setiap desa memiliki masjid-masjid yang tempanya strategis di tengah-tengah desa. Setiap waktu sholat masjid-masjid tersebut pasti terisi jamahaah-jamaah untuk melaksanakan sholat berjamaah.

Keadaan atau eksistensinya pondok tersebut tidak mengalami penurunan ketika meninggalnya kiayi pengasuh pondok, kiyai pondok tersebut meninggal kurang lebih 4 tahun yang lalu. Dan kini kepemimpinan diamanahkan sodaranya, sodaranya inilah yang melanjudkan keeksistensian pondok tersebut hingga saat ini, dari pondok pesantren tersebut banyak melahikan penghafal al-quran, kreatifitas dan seni-seni lainnya seperti kali grafi dan lukisan dan lain sebagainya.

Pondok tersebut mandiri, artinya dana atau pembangunana setengahnya merupakan dana dari usaha mandiri dan kreatifitas dari santri-santri dan dari dana hibah atau bantuan dari orang tua santri. 
Dan kini pembangunannya terus berjalan secara terprogram dan bertahap, para santripun ikut terlibat dalam proses pembanguan, karea para siswa di beri jadwal untuk membatu tukang batu memasang batu, misalnya pengasuh memberii izin santrinya dua orang sehari untuk membantu bekerja dan ini dilakukan secar bergiliran artinya jauga untuk memberikan pelatihan kepa para santri untuk bekerja keras dan mandiri. Sntri bukan hanya belajar dan belajar ilmu agama namun di bekali juga dengan ilmu lainnya yang sifatnya member pelatihan atau keterampilan. Sehingga ketika nanti santri lulus dari pondok santri bisa mandiri.

pondok pesantren tersebut mempunyaio cirri khas yang berbea dengan pondok pesantren lainnya, keunukan itu misalnya setiap minggu legi ini dalam bahasa jawa dilaksanakan pengajian yang dihadiri oleh para orantua santri atau kelompok majelis taklim, kemudian keunikan lainnya seperti RA, MI, MTS, dan Aliyah itu liburnya hari jumat yang pada umumya kan hari minggu itu lebur sekolah, tetapi di pondok pesantren sekolah di pomdok annur liburnya hari jumat daan hari minggu legi, karena minggu legi santri di wajibkan untuk mengikuti pengajian minggu legi atau ahad legi. Para siswapun di wajibkan menggunakan songkok atau kopiyah yang karena sebagai symbol sekolah madrasah yang besiknya agama, meskipin siswa yang tidak modok atau siswa luarpun duwajibkan untuk menggunakan songkok.

Sekolah yang ada di pondok pesantren annur azzubaidipun mampu bersaing engan sekolah-sekolah yang ada di sekitarnya, meskipun sekolah yang ada di pondok pesantren tersebur masih swasta namun mampu bersaing dengan sekolah negeri lainnya. Prestasi yang diraihpun sangat luar biasa bila dibandingkan dengan sekolah yang ada di sekitarnya. Kemudian dari saran dan prasarananyapun sangat menunjarng para siswa untuk proses pembelajaran. Perpustaan yang keadaannya baik yang terisi dengan buku-buku yang bisa di baca siswa untuk menambah wawasan para siswa, kemudian komputerpun madrasah aliyah memiliki computer yang dapat digunakan dalam proses pengembangan iptek sebagi penyesuaian perkembangan jaman.

Di pondok pesantren annur azzubaidi yang tanahnya sangat luas, sehingga pembangunannya dapat tersusun dengan rapi semua sekolah baik dari tingkat RA,MI,MTS dan MA, itu posisi bangunannya tidak terlalu jauh seakan-akan bersambung membentuk 
leter "o" ini lah yang membuat sekolah tersebut terlihat unik di tambah lagi sekolah tersebut dekat dengan perwsawahan dan kebun sawit sehingga suasana di sekolah tersebut sejuk dan asri. Jadi ketika siswa merasa bosan siswa bisa merefres sejenak pikirannya dengan melihat pemanadangan dan gunung-gunung kelapa sawit yang mengelilingi sekolah tersebut, jadi seakan-akan ketika kita berada di sekolah tersebut seakan-akan berada di sekolah terbuka karea suasana yang terlihat mencirikan pemandangan.

Sekolah di pondok peantren ketika hari senin ketika melaksanakan upacara itu terlihat banyak sekali karena ketika upacara bendera hari senin antara RA sampai MA itu di gabung di lapangan. Dan lapangan itupun terletak di tengah-tengah antara Mi, Mts dan Madrasah aliyah. Meskipun jarak sekolah antara Mi,Mts dan Madrasah Aliyah berdekatan namun tida menjadi masalah, karena ada batasan-batasan antara sekolah masing-masing.

Jadi perkembangan pembangunan bukan hanya dimadrasah aliayah tetapi perkembangn pembangunan ini merata menyeluruh setiap sekolah yang ada di lingkup pesantren tersebut. dan kini sedang melaksanakan pembangunan gedung MTS putrid bangunan yang sedang di garap ini sangat besar mencapai dua lantai, dan kini pembanguannya sudah hampir selesai dan akan siap di gunakan dalam proses pembelajaran. Pembangunan ini tentunya membutuhkan dana yang cukup tinggi, namun luar biasanya dana yang di gunakan dari dana yang diperoleh dari dana hibah dan hasil kreatih atau usaha mandiri pondok persantren tersebut.

Di sekolah tersebut ketika tiba waktu pulang namun kita tidak langsung pulang tetapi kita di wajibkan untuk sholat berjamaah terlebih dahulu sebelum pulnag kerumah masing-masing ini dilakukan untuk menjaga sholat agar melakukannya secaar berjamaah. Setelah selesai sholat baru para siswa di perbolehkan pulang dan apabila ada siswa yang terlambat melaksanakan sholat dhuhur terlambat maka siswa tersebut akan di kenakan sanksi, misalnya yang biasa dilakukan yaitu disuruh berdiri hal ini dilakukan untuk menberika efek jera kepa siswa yang bandel untuk melaksankan shoat dhuhur secara berjamaah di masjid.

Kemudian untuk para sntri baik yang putra mupun yang putrid ini di dominasi anak-anak yang berumur 11 sampai 12 tahun atau didominasi mereka mondok sejak kelas awal MTS, jadi untuk sekolah MI ini dipenuhi dengan anak sekitar pondok yang tempat tinggalnya 
diak jaug dari pondok pesantren tersebut, berbeda dengan MTS dan Madrasah Aliyah ini sebaliknya lebih didominasi dari anak-anak pondok, Jarang anak-anak yang tempat tinggalnya dekat dari pondok pesantren tersebut untuk melanjudkan di MTS atau Madrasah Aliyah. Ebtah factor apa yang menyebabkan mereka enggan melanjudkan di Madrasah Aliyah, entah itu factor biasya yang mahal dibandingkan dengan sekolah setingkat yang ada di sekitar kampung tersebut. mereka lebih meilih untuk melajudkan di SMKN atau SMAN.

Jika factor biaya yang menjadi beban masyarakat untuk menyekolahkan anak-anaknya disekolah tersebut, artinya masyarakat masih belum mengutamakan pendidikan semahal apapun jika itu untuk pendidikan mengapa tidak dilakukan, atau karena kurangnya pemahaman akan pentinggnya ilmu agama yang akan membekali siswa dalam bertingkah laku.

Di madrasah aliyah annur azzubaidi baru membuka program jurusan yaitu IPA dan IPS, mengenai jurusan ini sangatlah unuk semenjag di buka program jurusan IPA dan IPS, untuk program IPA ini lebih didominasi para siswa putri kemudian sebaliknay untuk jurusan IPS lebih didominasi siswa putra ini terjadi sejara berkelanjutan semenjak dibuka program jurusan tersebut.

Madrasah aliyah tersebut mempunyai program kegiatan antar antara madrasah yang ada di seluruh Sulawesi tenggara yaitu porseni. Porseni ini dilakukan setiap tahun dan dilaukan secara bergiliran dan madrasah aliyah annur sudah menjadi tuan rumah pelaksanaan porseni yang keskian kalinya, kegiatan ini dilakukan secara konsisten, hal ini dilakukan untuk mejalin perodaraan antar madrasah yang ada di Sulawesi tenggara.

Porseni ini bukan hanya dilakukan di tingkat madrasah tetapi juga di tingkat MTS, porseni ini juga dilaukan secar begiliran guna untuk menjalin hubungan antar MTS-MTS yang ada di Sulawesi tenggara. Harapan dari porseni ini sangat memberikan dampak yang positif, jadi bukan hannya porseni yang dilakukan tetapi menjalin demi kemajuan MTS.

Kemudian selama madrasaha aliyah berdiri, madrasah aliyah tersebut baru mengalami tiga kalai pergantian kepala sekolah, dari kepemimpinan kepala madrasah yang pertama yang dipimpin langsung oleh kiayi pondok pengasuh annun azzubaidi, dari kepemimpinan beliau sudah Nampak berkembang pesat kemajuan madrasah aliyah annur azzubaidi, setelah sekian beberapa tahun beliau 
menjabat sebagai kepala madrasah, beliau menghembuskan nafas kemudian digantikan ole hade kandungnya, adekandungnya kemudian meneruskan perjuangan beliau berkerja keras untuk memajukan sekolah tersebut, muwujudkan apa yang menjadi keinginan kepala madrasah yang pertama. Karena sebelum beliau meninggal dunia banyak rencana yang ingin beliau bangun untuk kemajuan madrasah aliyah, namun rencananya belum terealisasi beliau meninggal dunia karena sakit. Kemudian dilanjutkanlah apa yang menjadi harapannya. Dan apa uang menjadi harpannya itu sudah mulai terealisasi sedikait demi sekit, namun beliau juga belum dapat merealisasikan sepenuhnya karena belai sakit. Sakit yang beliau alami yai strok, dan kini kepimimpinannya sementara digantikan oleh salah satu guru yang merupakan guru tetap di lembaga tersebut. beliaulah yang akan melanjutkan apa yang telah menjadi keinginan dari kepala madrasah yang pertama atu kiyai pondok pesantren tersebut.

Beliau melanjukan kepemimpinannya kurang lebih baru dua tahun, namun dari dua tahun kepemimpinannya sudah Nampak ada perubahan besar yang yang Nampak terlihat di sekolah tersebut, banyak gedung-gedung yang mualai terbangun, diantaranaya ruang terbuaka yang di guanakan untuk melaksanakan proses pembelajaran di luar ruangan, klasi ini di gunakan pada saat guru dan siswa nerasa bosan untuk melakukan proses pembelajaran didalam ruangan, kemudia terbangun juga gedung perpustakaan abru, gedung ini yang di manfaatkan untuk para siswa membaca buku atau mengerakan tuaga yang apa bila mengharuskan untuk menbaca buku di perpustakaan. Dan dapat di manfaatkan siswa untuk membaca buku pada saat jam kosong. Kemudian terbangun juga kantin baru, yang mana sebelumnya sudah ada namun sekolah tersebut membangan kantin karena kantin yang pertaman selalu padat dengan pembeli, melihat padatnya pembeli sekolah tersebut membuat kantin lagi.

Berdasarkan dari hasil wawancara saya terhadap salah satu siswa, siswa lebih merasa senang ketiak belajar di ruang terbuka karena lebih sejuk dari pada di dalam ruangan siswa merasa bosan dengan belajar di dalam ruangan, yang mana menurut mereka sekolah tersebut belum di pasngkan AC sehingga ketiaka masuk jam ke dua atau jam ketiga siswa merasa jenuh dan bosan belajar di dalam ruangan, siswa lebih senang belajar dia ruang terbuka, karena di jam ke dua sudah mulai naik mataharinya dan keadaan atap sekolah tersebut menggunakan seng tentu itu akanmembuang suhu di dalam 
ruangan panas, apa lagi kalu masuk jam ketiga siswa capek setelah main sepak boal atau poli mereka meraka akan lebih panas jika belajr didalam ruangan. Untuk itu para siswa lebih suka dan memiliah untuk belajar di ruang terbuka. Dan posisi ruang terbuka pun persampingan dengan persawahan itu yang akan menambah kesejukan dan membuant semangan untuk belajar meski dalam keadaan capek dan lelah.

Perkebangan dan kemajuan pondok pesantren tersebut semakin pesat karena banyak perestasi yang di raih baik dari prestasi pondok maupun prestasi yang di raih oleh sekolah, akhinya banyak masyarkat yang tertarik untuk menyekolahkan dan memondokan anak-anaknya di sana. hal itu terlihat ketika pondok mengadakan MILAD atau ketika memperingati hari jadi atau berdirinya pondok persantren, semakintahun acara tersebut semakin rame karena orang tua dari para sntri pada datang utuk mengahadiri acara tersebut.

Ketika MILAD semua para wali santri dan alumni pada datang utuk menghadiri acara dan meramaikan acara tersebut, artinya rasa solidaritas di antara merekapun sangat kuat, ketiak mereka saling bertemu dengan ade-ade kelasnya atau dengan seniornya meraka saling berjaba tangan dan saling bercerita tentang ketika mereak mondok tentunya banyak suka dan duka ketiaka mondok.

Ketika acara MILAD banyak penampilan dari kereatifitas yang di tampilkan santri putra dan putri untuk menghibur tamu undangan dan sebagai pembelajaran karena derama-drama yang mereaka adekankan bersifat membangun perasaan kita umtuk mengitropeksi diri. Dalau dari putrid sering menampilkan lagu-lagu kasidah robana.

Dan setiap dua tahun pondok pesantren tersebut mampu mewisuda santriwan dan santri wati penghafal al quran 30 jus dan jus 30 ini dilakukan setiap dua tahun dan ini dilakukan sudah ke sekian kalinya. Kemudian banyak lulusan dari pondok atau madrasah aliyah tersebut yang mampu melanjutkan studinya untuk kuliah di perguruan tinggi ternama di Indonesia seperti di UGM dan UII dan lain sebagainya ini merupakan prestasi yang mebanggakan podok pesantren yang letaknya di tengahtengah kampung trans alumninya mampu menembus perguruan tinggi ternaman di Indonesia.

Dan ketika selesai MILAD para alumni mengadakan pertemuan untuk membahas mengenai kemajuan pondok, dan para alumni punya ini siatif setiap pertemuaan mengumpulkan uang iuraan untuk menyumbang kepondok tersebut sebagai rasa peduli dan 
sebagia sumbangsih atas ilmu yang telah di berikan atau atas didikan yang telah di peroleh ketika mondok. Dan ketika MILAD selalu mendatangkan atau mengundang ustad atau kiayi dari jawa untuk memberikan ceramah atau tausiah dalam rangka memperingati hari berdirinya pondok.

Ketika hari kemerdekaan indinesia pondok oesantren tersebut selalu membuat kegiatan yang dilakukan khusus santri-santri hal ini untuk menanamkan rasa perjuangan di dalam hati dan diri para santri, dan sebagai hiburan agar santri juga bukun hanya tau tentang sejarah islam namun harus tau juga sejarah bangsa Indonesia. dan antusias para santripun begitu semangat ketiak mengikuti kegitan lomba memperingati hari kemerdekaan Indonesia, bahkan pondok tersebut membuat group gerak jalan indah yang dilakukan keliling kampung sebagai bentuk bukti santri cinta akan negara Indonesia.

Tidak terhenti di situ ketiak menyambut hari raya idul adha pun bara santri berantusian untuk menyambutnya, sebelumnya para santri membuay obor dan lampion untuk merayakan malam takbiran, yang dilakukan dengan takbir keliling kampung, karena ketika idul adha santri tidak di izinkan untuk pulang kecuali hari raya idul fitri santri di izinkan untuk pulang kampung dan merayakan lebaran di kampung halaman. Dan santripun di beri batasan libur paling lama satu minggu kemudian harus kembali lagi kepaondok untuk menuntut ilmu, namun masihada saja santri yang molos kaiau dalam istilah pondok atau datang kepondok tidak tepat waktu tanggal berakhirnya liburan. Bagi santri yang molor di beri sanksi, dan sanksi ini di beriakn dengan maksid dan tujuan agar santri lebih konsisten dengan waktu, agar santri lebih disiplin dan jujur.

Kemudian ketika bulan ramadhan pondok dan sekolah yang ada dalam lingkup yayasan melaulkan kegiatan pesantern kilat, pesantren kilat ini biasa dilakukan selama 15 hari terkadang juga 20 hari tergantung dari kesepakatan guru-guru dan keputusan ketua yayasan pondok pesantren. Kemudian bagi santri ada kegiatan khusus yang harus di lakukan setelah selesai sahur ada kegiatan tausiah subuh yang di bawakan oleh para santri secara bergiliran hal ini bertujuan untuk melatih mental dan kemampuan santri untuk berpidato atau ceramah, ketika nanti kembai kekampung halaman masing-masing. Sebagai identitas sebagai santri di tuntut untuk bisa ceramah ketika pulang di kampung halaman. 
Didalam pesantren tersebut jatah makan dari para santri dalam satu hari makan tiga kali, pada saat pagi, sehabis duhur dan malam setelah sholat isya. Adapun kalau santri ingin makan di luar jam makan yang di beerikan oleh pondok maka santri bisa membeli makanan di kantin yang telah disediakan oleh sekolah.

Kemudian kegiatan santri pada saat libut sekolah atau pada saat hari jumat santri semua kerjabakti untuk membersihkan lingkungan pondok pesantren, santri menyapu seluruh halamnan memotong rumput dan merapikan bunga. Hal ini dilakukan secara serentak antara santri putra dan putrid, hal ini lebih dikenal dengan istilaah roan atau kerja bakti. Santri sangat didik dan di siplin dengan ketat terkadang santri ikut membantu gotong royong ubtuk menimbun, santrin dengan perpasang-pasangan sesame putrid untuk mengangkat pasir, agar pasir tidak terasa berat. Kalau untuk yang laki-lakinya menggunakan arco untuk menimbun. Karena tenaga laki-laki lebih kuat dari pada perempun.

Kemuduian mengenai keadaan guru-guru baik di lingkungan pondok atau sekolah, rata-rata guru-guru pondok yang mengajar di pesantren berdomisili di lingkungan pesantren hal ini akan memudahkan guru untuk mengar para santri dan memudahkan santri untuk menyetorkan hafalan kepada sang guru yang bersangkutan, ratarata guru-guru yang mengajar di pondok pesantren tersebut lulusan dari pondok pesantren tersebut atau alumni dari pondok tersebut, guru-gurunya pun ada yang lulusan sarjana S1 ada juga yang D2 dan ada juga yang hanya lulusan pondok saja. Namun kalau kita lihat kualtas guru-gurunya itu sangat luar biasa karena mampu mendidik murid-muridnya ada yang menjadi penghafal al quran, ada yang melanjudkan pendidikan keperguruan tinggi ternami di Indonesia ini merupakan hal yang sangat luar biasa.

Guru-guru pun mengajarnya merangkap mengajar di pondok pesantren sekaligus mengajar di sekolah yang ada di yayasan pondok pesantren annur azzubaidi, hanya ada beberapa guru yang dari luar pondok mengara di sekolah yang ada di pesantren tersebut. hubungan guru dengan para guru pun terjalin baik saling tegur sapa, mereka tidak merasa ada perbedaan antara guru yang tinggil di dalam amupun diluar pondok pesantren.

Selanjudnya untuk prestasi yang telah di raih oleh pondok pesantren atau sekolahpun sudah banyak, ada banyak sekali tersimpan di lemari piala-pialaya hasil prestasi para santri yang di peroleh dari 
berbagai prestasi yang diraihnya, salah satunya dari lomba cerdar cermat, lomba kaligrafi, lomba MTQ dan lain sebagainya. Dari hasil prestasi-prestasi yang telah di peroleh menunjukan bahwa pondok pesantren tersebut mampu membawa perubahan besar terhadap perkembangan dan pertumbuhan santri-santrinya.

Banyak juga lulusan dari pondok pesantren tersebut kemudian setelah lulus banyak santri-santri yang ketika pulang kampung mendirikan TPQ di kampung halamannya masing-masing, ada juga yang sudah berhasil mendirikan pondok pesantren namun masih dalam kategori merintis, masih banyak memnutuhkan dana untuk pembangunan.

Dan banyak juga alumni-alumni dari pondok pesantren tersebut kehidupannya alhamdulilah baik karena mereka memp[unyai keterampilan, seperti menjahit dan kesenian lainnya, banyak juga lulusan dari pondok persantren yang menjadi guru baik guru honorer maupun sebagai PNS dan ada juda sebagai wirausaha.

Ada banyak juga guru-guru pondok yang katekori penghafal alquran, tentu saja gru-guru inilah yang nantinya akan jug melahirkan santri-santri penghafal al quran, karena sudah banyak santri wati dan santriwan yang berkategori penghafal alquran 30 jus, kalau untuk kategori halfal jus 30 ada banyak dan hafal surah-surah pilihan seperti yasin, al kahfi, al mulk, ar rahman. Mereka santri di wajibkan untuk menghafalkan surah-surah pilihan tersebut.

Sekolah tersebut nampak asri karena bersampingan dengan persawahan dan perkebunan kelapa sawit serta di kelilingim pegunungan sehingga menjadiakan sekolah tersebut lebih nyaman dan sejuk. Banguna tersebut merupakan ruang terbuka bagi siswa untuk melaksanakan proses pembelajaran agar siswa tidak merasa bosen belajar dalam ruangan. Ruang terbuka tersebut bersampingan dengan perpustakaan sehingga siswa dapat membaca buku sambil melihat pemandangan persawahan.

\section{Kesimpulan}

Pengembangan lembaga pendidikan, baik itu sekolah berlabel agama atau non agama, tidak selalu berjalan dengan semangat persaingan. Dimana saat ini persaingan dianggap sebagai sebuah kewajaran untuk meraih keunggulan, yang juga dibenarkan dalam doktrin keagamaan, misalnya konsep fastabiqul khairat. Namun demikian, banyak pula lembaga pendidikan yang sangat berhati-hati 
dalam mengamalkan doktrin progresif keagamaan. Mereka khawatir bahwa semangat kompetisi dapat mengalihkan mereka pada semangat duniawi, bukan lagi niat suci mengabdi pada pencipta. Jiwa inilah yang terus dijaga oleh Pondok Pesantren Annur Azzubaidi. Terbukti pondok ini dapat bertahan hingga kini.

\section{Daftar Pustaka}

Badarwan, B. (2018). Perilaku Sukarela di Pesantren: Karakter Langka di tengah Pusaran Pragmatisme SDM Lembaga Pendidikan. Shautut Tarbiyah, 24(1), 19-36.

Ch, M. (2012). PESANTREN RAKYAT: Perhelatan Tradisi Kolaboratif Kaum Abangan dengan Kaum Santri Pinggiran Desa Sumberpucung Kabupaten Malang. El Harakah (terakreditasi), 14(1), 115-134.

Ghofur, A., Asiyah, N., \& Shofiyullah, M. (2017). Pesantren Berbasis Wirausaha (Pemberdayaan Potensi Enterpreneurship Santri di Beberapa Pesantren Kaliwungu Kendal). Dimas: Jurnal Pemikiran Agama untuk Pemberdayaan, 15(2), 19-52.

Ikhsanuddin, M., Millah, A. S., \& Machalli, I. (2013). Pengembangan Kurikulum Perguruan Tinggi Pesantren: Studi Pada Ma'had Al-'Aly Pondok Pesantren Situbondo, al-Munawwir Krapyak dan Wahid Hasyim Sleman. Jurnal Al-Nur, 5(2), 261-289.

Miles, M. B., \& Huberman, A. M. (1992). Analisis Data Kualitatif, penerjamah Tjerjeprohidi.

Moleong, L. J. (2006). Metode penelitian kualitatif edisi revisi. Bandung: Remaja Rosdakarya.

Mustari, M., \& Rahman, M. T. (2012). Ekonomi Pesantren: Manajemen Pesantren dalam Pembangunan Masyarakat Desa (Vol. 1, No. 1). Lintang Publishing.

Ramdhani, M. R. (2017). Implementasi Pendidikan Life Skill Di Pesantren Pertanian Darul Fallah Bogor. Tadbir Muwahhid, 4(2).

Sugiyono, P. (2005). Memahami penelitian kualitatif. Bandung: Alfabeta.

Supriatna, E., Bahruddin, E., Hafidhuddin, D., \& Saefuddin, D. (2014). Konsep dan Implementasi Pendidikan Karakter di Sekolah Menengah Kejuruan (SMK) Berbasis Pondok Pesantren. Ta'dibuna: Jurnal Pendidikan Islam, 3(2), 100-114. 
Syahrul, S. (2020). Strategi Pengembangan Lembaga Pendidikan: Menggali Spirit PM Gontor 7 Putera, Sulawesi Tenggara. Shautut Tarbiyah, 24(2), 334-360.

Syahrul, S. (2017). Tanggung Jawab Sosial Pesantren: Studi pada Pondok Pesantren Al Munawwarah Pondidaha, Konawe. Shautut Tarbiyah, 23(2), 120-134.

Syahrul, S. (2015). Kepemimpinan dan Inovasi Lembaga Pendidikan (Pengalaman Pondok Gontor VII Putra Sulawesi Tenggara). Al-Ta'dib, 8(1), 82-100.

Usman, M. I. (2013). Pesantren Sebagai Lembaga Pendidikan Islam (Sejarah Lahir, Sistem Pendidikan, Dan Perkembangannya Masa Kini). Jurnal al-Hikmah, 14(1), 127-146.

Wibowo, A. (2016). Peran Pondok Pesantren Al-Haidar Dan Pembinaan Remaja Desa Penjalin Brangsong Kendal (Doctoral dissertation, UIN Walisongo).

Widodo, M. S. (1995). Pesantren Darul Fallah: eksperimen pesantren pertanian. Pesantren dan Pembaharuan, 122-23. 